\title{
SYNTHESIS AND REGULATION OF TH2 CELL AND IL-4 AS TARGET FOR ASTHMA THERAPY
}

\author{
Lathifah Dzakiyyah Zulfa, Dessyani Salim, Lawrent Ernts Sumilat, dan Abigail \\ Tirza Melia Silalahi \\ Medicine Faculty of Universitas Kristen Indonesia \\ Email: lathifahdzakiyyahz@gmail.com,koletadessyani@gmail.com, \\ lawrentsumilat@gmail.com, dan abigail.silalahi@gmail.com
}

\begin{abstract}
One characteristic of asthma is the occurrence of respiratory tract hypersensitivity reactions in humans. The reaction is caused by an inflammatory reaction in the bronchial smooth muscle. Treatment for asthma is well known, such as bronchodilator drugs with the aim of reducing the response of the bronchial smooth muscle after receiving stimulation from pro-inflammatory cytokines. However, the use of bronchodilators has a variety of undesirable side effects. On the other hand, treatment therapy for hypersensitivity reactions in terms of the cause of the hypersensitivity reaction itself, in this topic IL-4 as a pro-inflammatory factor, is rarely discussed. Therefore, the purpose of this literature review is to review potential new therapeutic targets by targeting directly in $I L-4$ and Th2 regulation. Data collection is collected by searching on several studies and reviews that have been done. In this literature review it was found that it is possible to target new therapies for asthma problems through targeting IL-4, Th2, and transcription factors.
\end{abstract}

Keywords: Asthma, IL-4, Th2, Transcription Factors

\begin{abstract}
Abstrak
Salah satu karakteristik dari penyakit asma adalah terjadinya reaksi hipersensitivitas di saluran respirasi manusia. Hal ini disebabkan oleh reaksi peradangan pada otot polos pada bronkus. Pengobatan asma yang paling bayak diketahui adalah bronkodilator dengan prinsip kerjanya menurunkan respons otot polos bronkus terhadap sitokin - sitokin pro-inflamasi. Namun, penggunaan obat bronkodilator ini menyebabkan efek samping yang tidak diharapkan. Di sisi lain, pengobatan asma yang langsung menargetkan penyebab reaksi hipersensitivitas seperti faktor proinflamasi IL-4 jarang dibahas. Oleh karena itu, tinjauan literatur ini akan membahas potensi obat baru yang menargetkan regulasi IL-4 dan Th2. Kumpulan data diambil dengan cara mencari beberapa studi dan tinjauan yang sudah dilakukan sebelumnya. Dalam tinjauan literatur ini, ditemukan bahwa terdapat potensi obat asma yang menargetkan langsung ke IL-4, Th2, dan faktor transkripsi.
\end{abstract}

Kata Kunci: asma; IL-4; Th2; faktor transkripsi

\begin{tabular}{ll}
\hline How to cite: & Zulfa, Lathifah Dzakiyyah., et.al. (2021) Synthesis and Regulation Of Th2 Cell And Il-4 As Target \\
& For Asthma Therapy. Syntax Literate: Jurnal Ilmiah Indonesia. 6(4). http://dx.doi.org/ \\
& $10.36418 /$ syntax-literate.v6i4.2527
\end{tabular}




\section{Introduction}

Airway Hyperresponsiveness (AHR) is a characteristic of asthma patiens which consists of two things, airway hypersensitivity, which is the abnormal airway smooth muscle response to the minimum stimulus, and the hyperreactivity of airway smooth muscle that causes bronchoconstriction response (Keglowich \& Borger, 2015).
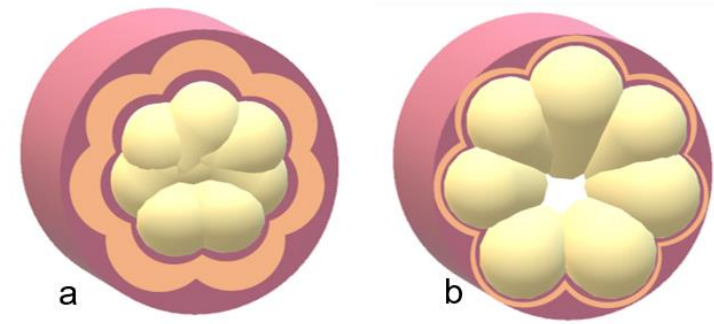

Figure 1. (a): Bronchoconstriction, (b): Normal Bronchial Tube

Eosinophils are closely related to these conditions and produce TGF- $\beta 1$ which 'promotes' fibroblasts proliferation, myofibroblast maturation, and collagen synthesis. The active mature myofibroblasts will produce collagen I and III, tenascin, and fibronectin, which will increase in deposition and cause thickening of the basalis membrane of the airway. In the submucosa, eosinophils and mast cells produce several angiogenic factors including VEGF which cause increased vascularization. IL-5 produced by Th2 cells plays a role in recruiting eosinophils to organ tissues, and together with GM-CSF produced by Th GM-CSF, locally maintains eosinophils in tissues (Possa, Leick, Prado, Martins, \& Tibério, 2013). Th2 also secretes IL-4 which triggers epithelial cell hypertrophy; hence it plays an important role in the pathogenesis of asthma. However, it turns out that IL-4 can also induce differentiation from helper T cells (Th) naïve to Th2 cells, so that a straight comparison between the amount of IL-4 produced with Th cell differentiation is called positive feedback (Yamane \& Paul, 2012). Targeting that cell or what it produce for asthma treatment is seemed promising so that this literature review has been made. 


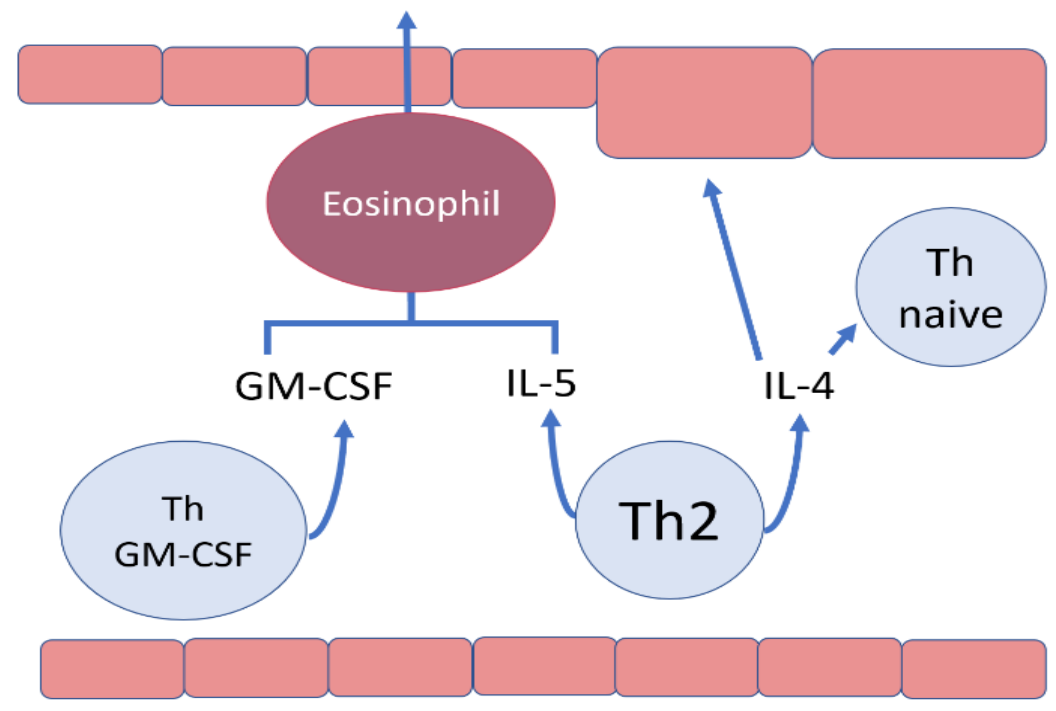

Figure 2. Asthma pathophysiology

\section{Method}

Authors were looking for novel therapeutic target for asthma by reading open access research and review papers on Google Scholar, Pubmed, Research Gate, etc. Knowing some targets related to each other (after brainstorming it) make author search deeper into it. After making an outline about asthma definition, its pathogenesis, and some drug finding, writter decide to start writting while keep looking for data sources on the same platforms.

\section{Result and discussion}

The fundamental question after reading the loop on introduction is where did Th2 and IL-4 come from. T cells themselves have been around since the embryonic period, but the form of these stem cells needs to be activated until finally they become Th cell, with a unique event in the thymus that ensures it does not fight body tissue protein. That gland is assisted by phagocytic cells to destroy reactive T cells during the process of self-antigen mixing (Hall \& Guyton, 2016). T cells have many types after differentiation but this discussion will focus on differentiation of Th2 with 3 stages, those are initiation, reinforcement, and maintenance. We are going to focus on initiation with exogenous IL-4 (the term for IL-4 not from TH2) which occurs shortly after the attachment of IL-4 to the specific IL-4 receptor (Zhu et al., 2002). IL-4 is not only produced from the differentiation of Th2 cells, but is also produced by NK T cells, basophils, mast cells, and eosinophils (van Panhuys et al., 2011). The process will eventually produce a signal that activates the transcription of IL4, GATA-3 and TH2 commitments after previously transduced by STAT6. The signaling process does not stop just like that but repeatedly so that at this stage it is called reinforcement. Autocrine and paracrine signals are continuously rotated so that commitment is strengthened, although our focus is on IL4, in fact it does not work alone, STAT5 and IL2 help to stabilize the signal. The long journey ends with maintaining the identity of cells that 
have been differentiated in the maintenance process with the help of GATA-3 (Zhu et al., 2002).

The initiation process requires IL-4R which is divided into types I and II receptors. IL-4R $\alpha$ together with the $\gamma c$ chain will form a type I receptor that connect with janus kinase (JAK). IL-4R $\alpha$ together with IL-13R $\alpha$ will form a type II receptor (Luzina et al., 2012).

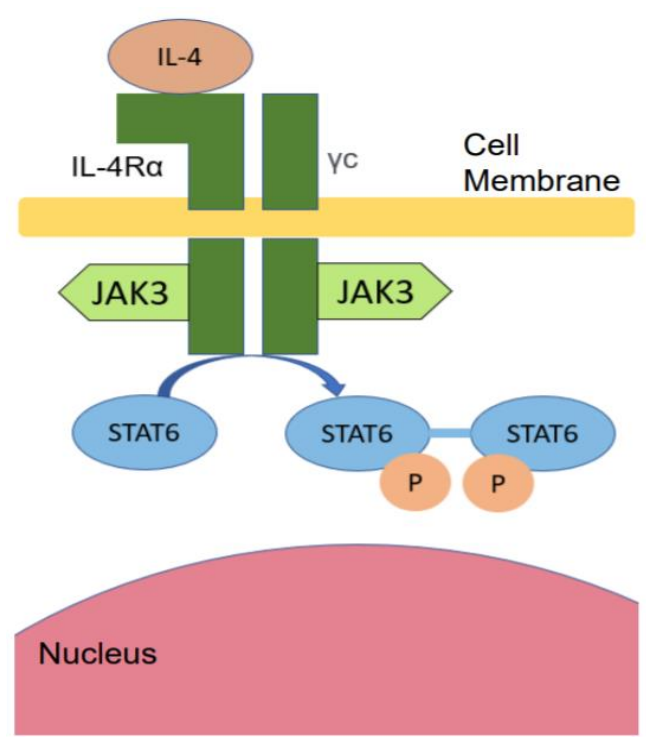

Figure 3.IL-4R type 1

Treatment for asthma with dissolved IL-4 receptors (sIL-AP4R) is very promising. sIL-4R binds to IL-4, and does not cause cellular activation of cytokines. John W Steinke and Larry Borish in their study conducted clinical trials with rhuIL-4R (NuvanceTM) with $1.5 \mathrm{mg}$ rhuIL-4R treatment showing anti-inflammatory effects (Steinke \& Borish, 2001). 


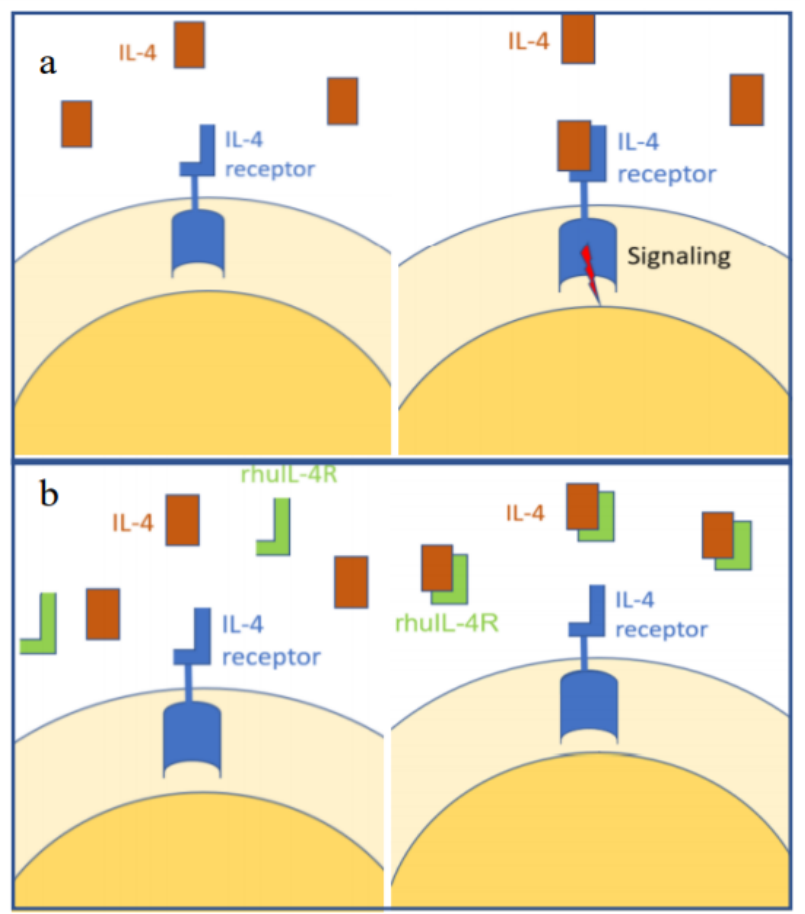

Figure 4.(a): Without rhulL-4R, (b): With rhulL-4R

Some transcription factors have been mentioned above such as GATA-3 and STAT6 but will be explained in more detail in this section which shows that how Th2 produces IL-4. The first transcription factor that plays a role in the formation of IL-4 is AP-1. AP-1 as a transcription factor has a role in IL-4 pro-inflammatory factors formation and eosinophil recruitment (Nguyen et al., 2003). It is not only AP-1 that plays a role in the formation of IL-4 as a transcription factor, but also the C / EBP transcription factor (Roth \& Black, 2006). C / EBP has many isoproteins which must be kept in balance because of their function to initiate the formation of various kinds of pro-inflammatory factors and cell proliferation (Roth \& Black, 2006). Some C / EBP isoproteins play a role in eosinophil differentiation and increased expression of IL-4 (Roth \& Black, 2006). There is also a specific cell lineage, GATA3, which can also activate IL-4 expression, and then through an independent pathway can activate other pro-inflammatory cytokines (Kishikawa, Sun, Choi, Miaw, \& Ho, 2001); (Zhang et al., 2001); (Zhang et al., 2001). The last transcription factor that is thought to play a role in the formation of IL-4 is STAT6. Although the work of STAT6 is to initiate the formation of IL-4, activation of STAT6 requires IL-4 as well, and then subsequently will produce IgE as well (Matsukura et al., 1999). This is why there can be positive feedback that can worsen the incidence of asthma. There are still a number of other transcription factors such as NFkB and $\mathrm{NrF} 2$ / ARE but do not have a significant impact on the formation of IL-4 (Roth \& Black, 2006); (De Bosscher, Vanden Berghe, \& Haegeman, 2003); (Funkhouser et al., 2004); (Kumar, Takada, Boriek, \& Aggarwal, 2004). New treatment targets are offered to target the four transcription factors previously discussed, namely AP-1, C / EBP, GATA-3, and STAT6. AP-1 activity can 
be inhibited by targeting oxidoreductase in human epithelial cells using PNRI-299 so as to reduce the formation of eosinophils and IL-4 (Roth \& Black, 2006). C / EBP can also be inhibited by several means, firstly the inhibition can be done by inhibiting C / EBP transport, by using ceramide (Park, Cho, \& Kim, 2004), secondly it can be interfered with C / EBP binding with DNA sequences using curcumine (Balasubramanian \& Eckert, 2004), and finally the formation of mRNA from C / EBP transcription can also be inhibited by using Trichostatin A (Lagace \& Nachtigal, 2004). For transcription factors GATA-3 and STAT6 each can be given antisense oligonucleotide (Finotto et al., 2001) and glucocorticoids (Roth \& Black, 2006).

\section{Conclussion}

In this review explained that drug options for asthma therapy keep growing such us targeting on IL-4 or its synthesis pathway. Inhibiting IL-4 to bind with its receptor with rhulL-4 shows efficacy on sufferer with minimum side effect and weekly drug use higher the drug half-life around five days more. Some transcription factor like AP-1, C/EBP, GATA-3, and STAT6 can also be the novel therapy target that reducing inflammation symptom, eosinophil recruitment and differentiation, and IL-4 or even other pro-inflammatory cytokines (because it acts as IL-4 producing factor and activation). The explanation above gives broad drug choice for clinician and knowledge for further research about asthma or other inflammation disease on molecular level. 


\section{BIBLIOGRAFI}

Balasubramanian, Sivaprakasam, \& Eckert, Richard L. (2004). Green tea polyphenol and curcumin inversely regulate human involucrin promoter activity via opposing effects on CCAAT/enhancer-binding protein function. Journal of Biological Chemistry, 279(23), 24007-24014. Google Scholar

De Bosscher, Karolien, Vanden Berghe, Wim, \& Haegeman, Guy. (2003). The interplay between the glucocorticoid receptor and nuclear factor- $\kappa \mathrm{B}$ or activator protein-1: molecular mechanisms for gene repression. Endocrine Reviews, 24(4), 488-522. Google Scholar

Finotto, Susetta, De Sanctis, George T., Lehr, Hans A., Herz, Udo, Buerke, Michael, Schipp, Mechthild, Bartsch, Brigitte, Atreya, Raja, Schmitt, Edgar, \& Galle, Peter R. (2001). Treatment of allergic airway inflammation and hyperresponsiveness by antisense-induced local blockade of GATA-3 expression. The Journal of Experimental Medicine, 193(11), 1247-1260. Google Scholar

Funkhouser, Ann W., Kang, Jeong Ah, Tan, Alan, Li, Jing, Zhou, Limei, Abe, Mark K., Solway, Julian, \& Hershenson, Marc B. (2004). Rhinovirus 16 3C protease induces interleukin-8 and granulocyte-macrophage colony-stimulating factor expression in human bronchial epithelial cells. Pediatric Research, 55(1), 13-18. Google Scholar

Hall, J. E., \& Guyton, A. C. (2016). Body temperature regulation and fever. Guyton and Hall Textbook of Medical Physiology. 13th Ed. Philadelphia, PA: Elsevier. Google Scholar

Keglowich, L. F., \& Borger, P. (2015). The three A's in asthma-airway smooth muscle, airway remodeling \& angiogenesis. The Open Respiratory Medicine Journal, 9, 70. Google Scholar

Kishikawa, Hiroko, Sun, Jenny, Choi, Andrew, Miaw, Shi Chuen, \& Ho, I. Cheng. (2001). The cell type-specific expression of the murine IL-13 gene is regulated by GATA-3. The Journal of Immunology, 167(8), 4414-4420. Google Scholar

Kumar, Ashok, Takada, Yasunari, Boriek, Aladin M., \& Aggarwal, Bharat B. (2004). Nuclear factor- $\mathrm{BB}$ : its role in health and disease. Journal of Molecular Medicine, 82(7), 434-448. Google Scholar

Lagace, Diane C., \& Nachtigal, Mark W. (2004). Inhibition of histone deacetylase activity by valproic acid blocks adipogenesis. Journal of Biological Chemistry, 279(18), 18851-18860. Google Scholar

Luzina, Irina G., Keegan, Achsah D., Heller, Nicola M., Rook, Graham A. W., SheaDonohue, Terez, \& Atamas, Sergei P. (2012). Regulation of inflammation by interleukin-4: a review of "alternatives." Journal of Leukocyte Biology, 92(4), 753764. Google Scholar 
Lathifah Dzakiyyah Zulfa, Dessyani Salim, Lawrent Ernts Sumilat, dan Abigail Tirza Melia Silalahi

Matsukura, Satoshi, Stellato, Cristiana, Plitt, James R., Bickel, Carol, Miura, Katsushi, Georas, Steve N., Casolaro, Vincenzo, \& Schleimer, Robert P. (1999). Activation of eotaxin gene transcription by NF- $\mathrm{KB}$ and STAT6 in human airway epithelial cells. The Journal of Immunology, 163(12), 6876-6883. Google Scholar

Nguyen, $\mathrm{Cu}$, Teo, Jia Ling, Matsuda, Akihisa, Eguchi, Masakatsu, Chi, Emil Y., Henderson, William R., \& Kahn, Michael. (2003). Chemogenomic identification of Ref-1/AP-1 as a therapeutic target for asthma. Proceedings of the National Academy of Sciences, 100(3), 1169-1173. Google Scholar

Park, I. Na, Cho, Il Je, \& Kim, Sang Geon. (2004). Ceramide negatively regulates glutathione S-transferase gene transactivation via repression of hepatic nuclear factor-1 that is degraded by the ubiquitin proteasome system. Molecular Pharmacology, 65(6), 1475-1484. Google Scholar

Possa, S. S., Leick, E. A., Prado, C. M., Martins, M. A., \& Tibério, IFlC. (2013). Eosinophilic inflammation in allergic asthma. Front Pharmacol 4: 46. Google Scholar

Roth, M., \& Black, J. L. (2006). Transcription factors in asthma: are transcription factors a new target for asthma therapy? Current Drug Targets, 7(5), 589-595. Google Scholar

Steinke, John W., \& Borish, Larry. (2001). Th2 cytokines and asthma-Interleukin-4: its role in the pathogenesis of asthma, and targeting it for asthma treatment with interleukin-4 receptor antagonists. Respiratory Research, 2(2), 1-5. Google Scholar

Van Panhuys, Nicholas, Prout, Melanie, Forbes, Elizabeth, Min, Booki, Paul, William E., \& Le Gros, Graham. (2011). Basophils are the major producers of IL-4 during primary helminth infection. The Journal of Immunology, 186(5), 2719-2728. Google Scholar

Yamane, Hidehiro, \& Paul, William E. (2012). Memory CD4+ T cells: fate determination, positive feedback and plasticity. Cellular and Molecular Life Sciences, 69(10), 1577-1583. Google Scholar

Zhang, Dong Hong, Yang, Liyan, Cohn, Lauren, Parkyn, Lisa, Homer, Robert, Ray, Prabir, \& Ray, Anuradha. (2001). Inhibition of allergic inflammation in a murine model of asthma by expression of a dominant-negative mutant of GATA-3. Immunity, 11(4), 473-482. Google Scholar

Zhu, Jinfang, Guo, Liying, Min, Booki, Watson, Cynthia J., Hu-Li, Jane, Young, Howard A., Tsichlis, Philip N., \& Paul, William E. (2002). Growth factor independent-1 induced by IL-4 regulates Th2 cell proliferation. Immunity, 16(5), 733-744. Google Scholar 


\section{Copyright holder:}

Lathifah Dzakiyyah Zulfa, Dessyani Salim, Lawrent Ernts Sumilat, dan Abigail Tirza Melia Silalahi (2021)

\section{First publication right:}

Journal Syntax Literate

This article is licensed under:

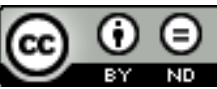

